\title{
Bioaerosols in the Amazon rain forest: Temporal variations and vertical profiles of Eukarya, Bacteria and Archaea
}

\author{
Maria Prass ${ }^{1}$, Meinrat O. Andreae $e^{2,3}$, Alessandro C. de Araùjo ${ }^{4}$, Paulo Artaxo ${ }^{5}$, Florian Ditas ${ }^{1, a}$, Wolf- \\ gang Elbert ${ }^{1}$, Marco Aurélio Franco ${ }^{1,5}$, Isabella Hrabe de Angelis ${ }^{1}$, Jürgen Kesselmeier ${ }^{1,2}$, Thomas \\ Klimach $^{1}$, Leslie Ann Kremper ${ }^{1}$, Eckhard Thines ${ }^{6,7}$, David Walter ${ }^{1}$, Jens Weber ${ }^{1}$, Bettina Weber ${ }^{1,8}$, \\ Bernhard M. Fuchs ${ }^{9}$, Ulrich Pöschl ${ }^{1}$, and Christopher Pöhlker ${ }^{1}$
}

\begin{abstract}
1 Multiphase Chemistry Department, Max Planck Institute for Chemistry, 55128 Mainz, Germany
2 Biogeochemistry Department, Max Planck Institute for Chemistry, 55128 Mainz, Germany

3 Scripps Institution of Oceanography, University of California San Diego, La Jolla, CA 92083, USA

4 Empresa Brasileira de Pesquisa Agropecuária (EMBRAPA), Belém, PA, Brazil

5 Institute of Physics, University of São Paulo, São Paulo 05508-900, Brazil

6 Institute for Microbiology and Wine Research, Johannes Gutenberg University Mainz, 55128 Mainz, Ger-

many

7 Institute of Molecular Physiology, Johannes Gutenberg University, 55128 Mainz, Germany

8 Department of Biology, University of Graz, Holteigasse 6, 8010, Graz, Austria

9 Department of Molecular Ecology, Max Planck Institute for Marine Microbiology, 28359 Bremen, Germany

a now at: Hessisches Landesamt für Naturschutz, Umwelt und Geologie, 65203 Wiesbaden, Germany
\end{abstract}

Correspondence: Christopher Pöhlker (c.pohlker@mpic.de) and Maria Prass (m.prass@mpic.de) 
https://doi.org/10.5194/bg-2020-469

Preprint. Discussion started: 18 January 2021

(c) Author(s) 2021. CC BY 4.0 License.

\section{Abstract}

The Amazon rain forest plays a major role in global hydrological cycling and biogenic aerosols are likely to influence the formation of clouds and precipitation. Information about the sources and altitude profiles of primary biological aerosol particles, however, is sparse. We used fluorescence in situ hybridization (FISH), a molecular biological staining technique largely unexplored in aerosol research, to investigate the sources and spatiotemporal distribution of Amazonian bioaerosols on domain level. We found wet season bioaerosol number concentrations in the range of $1-5 \cdot 10^{5} \mathrm{~m}^{-3} \mathrm{ac}-$ counting for $>70 \%$ of the coarse mode aerosol. Eukaryotic and bacterial particles predominated, with fractions of $\sim 56 \%$ and $\sim 26 \%$ of the intact airborne cells. Archaea occurred at very low concentrations. Vertical profiles exhibit a steep decrease of bioaerosol numbers from the understory to $325 \mathrm{~m}$ height on the Amazon Tall Tower Observatory, with a stronger decrease of Eukarya compared to Bacteria. Considering earlier investigations, our results can be regarded as representative for near-pristine Amazonian wet season conditions. The observed concentrations and profiles provide unprecedented insights into the sources and dispersion of different types of Amazonian bioaerosols as a solid basis for model studies on biosphere-atmosphere interactions such as bioprecipitation cycling. 


\section{Introduction}

The study of atmospheric bioaerosols represents a challenging field in aerosol research because of their diverse particle properties, including size, morphology, mixing state, hygroscopic behavior, and metabolic activity. Bioaerosols are ubiquitous in the atmosphere worldwide and comprise prokaryotic (Bacteria and Archaea) and eukaryotic (e.g., fungi and algae) cells, various reproductive entities (e.g., spores and pollen) as well as fragments of biological material (Andreae and Crutzen, 1997; Jaenicke et al., 2005; Després et al., 2012). The scientific as well as socioeconomic attention that bioaerosols have received can be explained by their manifold and fundamental roles in atmospheric chemistry and physics, biogeography, public health, ecology, and agriculture (e.g., Pöschl et al., 2010; Morris et al., 2014, Fröhlich-Nowoisky et al., 2016; Reinmuth-Selzle et al., 2017). To date, central aspects of their mechanistic roles and relevance in these fields are not fully understood or even largely unexplored. Progress in our understanding is hampered by analytical limitations in resolving the complexity, diversity, and highly dynamic life cycle of bioaerosols in the atmosphere (Morris et al., 2011; ŠantlTemkiv et al., 2019). Particularly scarce are techniques that provide atmospheric number concentrations for specific and clearly defined organism groups within the bioaerosol population.

The number of bioaerosol field observations worldwide is constantly increasing (Després et al., 2012; Fröhlich-Nowoisky et al., 2016; Šantl-Temkiv et al., 2019) with bioaerosol studies in regions that are essential for the climate system being particularly relevant. This refers to the oceans as well as forested ecosystems, which cover large areas of the Earth and entail intense surface-atmosphere interactions (e.g., Bonan, 2008; Artaxo et al., under revision; Mayol et al., 2014). Moreover, certain (though increasingly few) regions of the oceans and the large forests are still sufficiently unperturbed by man-made emissions and activities to approximate a preindustrial and, thus, pristine state of the atmosphere (Hamilton et al., 2014; Pöhlker et al., 2018). Along these lines, it has remained largely unknown which mechanistic roles "[bio]aerosols before pollution" (Andreae, 2007) have played in biogeochemical and hydrological cycles and to what extent such processes have been perturbed by the nowadays pervasive man-made emissions and activities. One important topic in this context is the ability of certain bioaerosols to act as efficient ice nuclei (IN) at comparatively warm temperatures (i.e., > $-10^{\circ} \mathrm{C}$ ) with important implications for cloud microphysics and precipitation formation (e.g., Morris et al., 2014; Delort et al., 2010).

30 The analytical and scientific novelty of this study is threefold: First, it widens the spectrum of techniques for bioaerosol investigations by exploring the analytical potential of fluorescence in situ hybridization (FISH) in this field. FISH is a molecular genetic technique for the specific staining of cells by targeting characteristic RNA or DNA sequences with complementary and fluorescently labeled nucleotide probes (e.g., Amann and Fuchs, 2008). In terrestrial and marine microbiology, FISH has become an important technique in identification and enumeration of microbial organisms with numerous applications (e.g., Pernthaler et al., 2004; Christensen et al., 1999). However, applications in bioaerosol research have remained remarkably sparse (Yoo et al., 2017; Harrison et al., 2005). Our 
results demonstrate that FISH has great potential in bioaerosol analysis as it provides number concentrations of specific organism classes (i.e., from domain down to species level) and, therefore, combines bioaerosol identification and quantification. Second, this study provides number concentrations for prokaryotic and eukaryotic cells in the Amazonian rain forest atmosphere under almost pristine conditions, which is unique data for this globally important ecosystem. In fact, the atmospheric Bacteria and Archaea concentrations are the first published results of this type for a tropical rain forest environment (Table S3). The concentrations obtained here can serve as a reference for modelling and process studies on climate-relevant forest-atmosphere interactions such as bioprecipitation-cycles. Third, this study has utilized the tall tower at the remote ATTO site to obtain vertical gradients of Bacteria,

10 Archaea, and Eukarya concentrations over the rain forest (with sampling heights at 5, 60, and $325 \mathrm{~m}$ ). These gradients allow to estimate concentration ranges for bacterial, archaeal, and eukaryotic cells touching the cloud base and, thus, to assess their potential relevance for cloud microphysics.

The samples for this study were collected during prevailing clean wet season conditions in the Amazon when the bioaerosol population originates from the primary rain forest region within the

15 ATTO site's footprint. A detailed characterization of the sampling conditions can be found in the Supplement. The FISH protocol used in this work is an adaptation of pre-existing protocols (Glöckner et al. 1996; Pernthaler et al. 2004) with modifications and optimizations for the specific requirements of bioaerosol analysis. The main experimental steps of the FISH protocol are illustrated and (briefly) explained in Figure 1. A focal point of this study has been the careful cross-validation and comparison

20 of the obtained FISH results with online aerosol data as well as a synthesis with existing literature knowledge. This validation is important since FISH is experimentally demanding and prone to various artifacts (i.e. false positive or false negative counts) and thus may yield biased results (Thiele et al, 2011). Overall, we found a high consistency with complementary online data from the ATTO site as well as from previous studies, which underlines that the obtained organism concentrations are a solid representation of the Amazonian wet season bioaerosol population. 

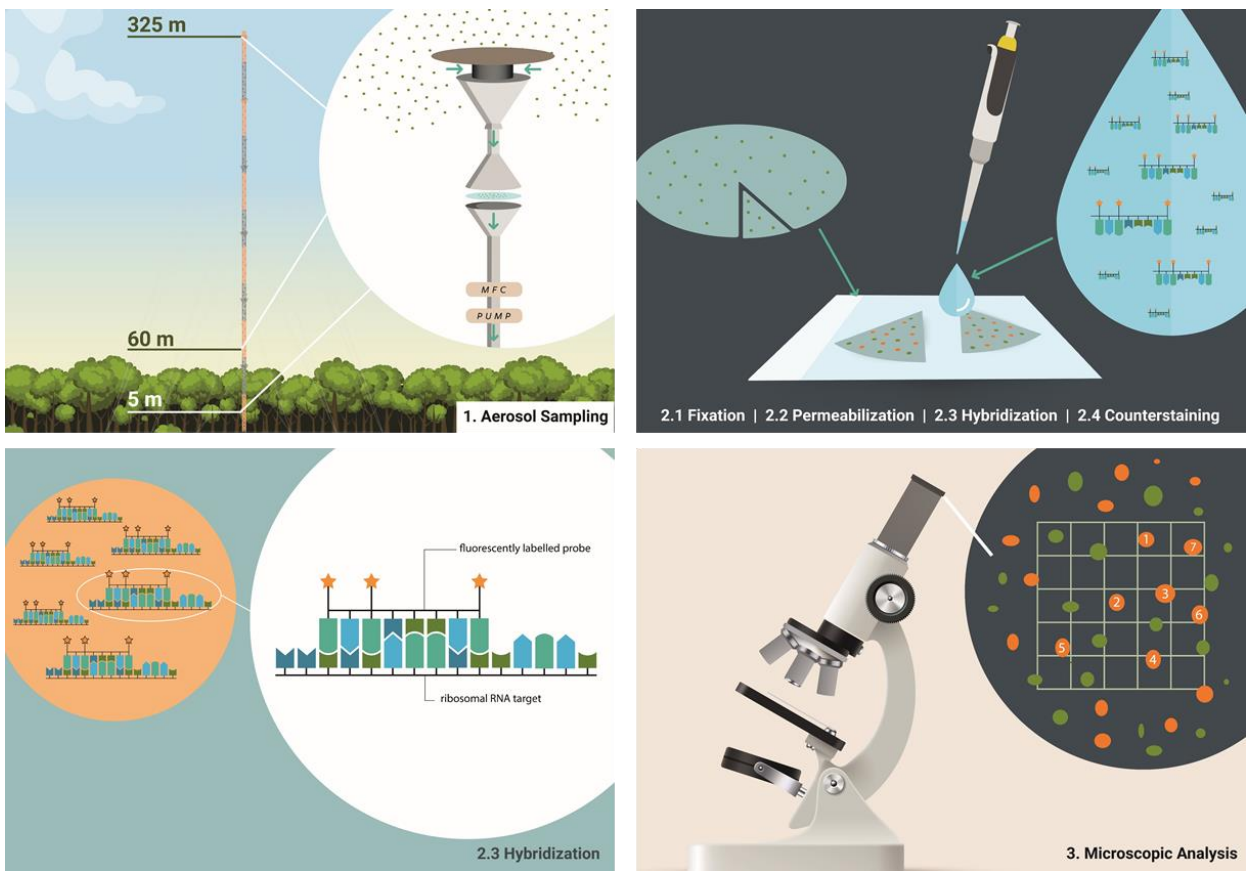

Figure 1. Bioaerosol sampling strategy in the Amazon rain forest and molecular genetic staining for microscopic identification and quantification. 1. Bioaerosols were collected on polycarbonate membranes at three different sampling heights at ATTO. 2. Biological material on the filters was prepared for staining by fixation and cell wall permeabilization. Then, fluorescently labeled oligonucleotide probes were used to assign bioaerosols at the domain level in a hybridization step. Overall bioaerosol numbers were obtained by DNA-staining with DAPI, the so called counterstaining 3 . Fluorescence signals were systematically enumerated and converted into atmospheric bioaerosol number concentrations.

\section{Results and discussion}

In the wet season atmosphere at the ATTO site Eukarya and Bacteria accounted for the majority of cells, whereas Archaea occurred at lower numbers and appeared to be rather rare in the investigated bioaerosols. At all sampling heights, the number concentration of eukaryotic cells ( $N_{\text {EUK}}$ ) was highest ranging from $\sim 3.5-38 \cdot 10^{4} \mathrm{~m}^{-3}$, followed by Bacteria $\left(N_{B A C}\right)$ ranging from $\sim 3.0-7.0 \cdot 10^{4} \mathrm{~m}^{-3}$, and Archaea $\left(N_{\text {ARC }}\right.$ ) ranging from $\sim 0.1-1.3 \cdot 10^{4} \mathrm{~m}^{-3}$ (Table 1, Figure 2 ). These numbers are in good agreement with estimated and measured concentrations in previous bioaerosol studies (e.g., Burrows et al., 2009b; Fröhlich-Nowoisky et al., 2016). For instance, our measured $N_{\text {BAC }}$ values fall within the estimated range of bacterial cell concentrations for forest ecosystems (i.e., 3.3-8.8 $10^{4} \mathrm{~m}^{-3}$ ) according to Burrows et al. (2009a). Of further atmospheric relevance is the number concentration of all airborne cells that were determined by staining the intracellular DNA with the fluorescent dye DAPI ${ }^{1}\left(N_{\text {DAPI }}\right)$.

${ }^{1}$ DAPI $=4$ ',6-Diamidin-2-phenylindol is a widely used fluorescent stain for DNA. 
Here, $N_{\text {DAPI }}$ ranged on average from $\sim 12-53 \cdot 10^{4} \mathrm{~m}^{-3}$ (Tables 1 and 2). Due to the given specificity of the FISH probes ( 80-90\% of all target cells according to the SILVAref138.1 database, www.arbsilva.de, last access 08 Dec 2020), a certain fraction of cells remains unclassified (i.e., $N_{\text {FISH }}<N_{\text {DAPI }}$ with $N_{\text {FISH }}=N_{\text {ARC }}+N_{\text {BAC }}+N_{\text {EUK }}$ ). In this study, $N_{\text {FISH }}$ accounted for $\sim 60-90 \%$ of $N_{\text {DAPI }}$ (Table 1 ,

5 Supplementary Table S1), which indicates a good performance of the FISH protocol (Thiele et al., 2011, and references therein).

Table 1. Bioaerosol number concentrations at different heights (avg $\pm s d ; n=5-6$, samples for $\sim 23 h$ at each height) on domain level (Archaea, Bacteria, and Eukarya) obtained by FISH. In addition, overall bioaerosol concentrations obtained by DAPI staining. Last column shows the fraction of cells that could be assigned to one of the domains by FISH in relation to the DAPI-derived concentration.

\begin{tabular}{cccccc} 
height & $\begin{array}{c}\text { Archaea } \\
{\left[\cdot 10^{4} \mathrm{~m}^{-3}\right]}\end{array}$ & $\begin{array}{c}\text { Bacteria } \\
{\left[\cdot 10^{4} \mathrm{~m}^{-3}\right]}\end{array}$ & $\begin{array}{c}\text { Eukarya } \\
{\left[\cdot 10^{4} \mathrm{~m}^{-3}\right]}\end{array}$ & $\begin{array}{c}\text { DAPI } \\
{\left[\cdot 10^{4} \mathrm{~m}^{-3}\right]}\end{array}$ & $\begin{array}{c}\text { fraction } \\
\text { probe/DAPI }\end{array}$ \\
\hline $5 \mathrm{~m}$ & $0.25 \pm 0.38$ & $7.0 \pm 2.1$ & $38 \pm 15$ & $53 \pm 21$ & 0.86 \\
$60 \mathrm{~m}$ & $1.3 \pm 1.2$ & $6.5 \pm 2.5$ & $14 \pm 3.3$ & $25 \pm 10$ & 0.85 \\
$325 \mathrm{~m}$ & $0.10 \pm 0.21$ & $3.0 \pm 1.3$ & $3.5 \pm 1.2$ & $12 \pm 4.6$ & 0.61
\end{tabular}

Figure 2 shows the time series of $N_{\mathrm{EUK}}, N_{\mathrm{BAC}}, N_{\mathrm{ARC}}$, and $N_{\text {DAPI }}$ at $60 \mathrm{~m}$ height with complementary meteorological and aerosol data under pristine rain forest conditions. Here, the total aerosol particle count between $\sim 0.7$ and $10 \mu \mathrm{m}\left(N_{0.7-10}\right)$ - corresponding to the effectively DAPI- and FISH-counted size range - serves as a reference number concentration and ranges from $\sim 30-48 \cdot 10^{4} \mathrm{~m}^{-3}$ (Table 2). Relative to $N_{\text {DAPI }}$, Eukaryotes accounted on average for $\sim 56 \%$, Bacteria for $\sim 26 \%$, and Archaea for $\sim 5 \%$ of the cells. The bioaerosol number concentrations $N_{\text {EUK }}, N_{\text {BAC }}, N_{\text {ARC }}$, and $N_{\text {DAPI }}$ show a clear day-to-day variability: For instance, $N_{\text {EUK }}$ varies by a factor of 2, whereas $N_{\text {BAC }}$ varies by a factor of 4 (Table S1). $N_{\mathrm{ARC}}$ shows even larger variations, although the low counting statistics here require caution in interpreting these results. ${ }^{2}$ Along these lines, also the bioaerosol mixture - i.e., the ratios of $N_{\text {EUK }}, N_{\text {BAC }}$, and $N_{\text {ARC }}$ relative to $N_{\text {DAPI }}$ as represented by the Pie charts in Figure 2 - show a clear variability. Here the days from 1 to 3 Mar 2018 stand out as they are characterized by a rather high abundance of $N_{\mathrm{BAC}}$. This increase in $N_{\mathrm{BAC}}$, might be related to the strong rain event in the night from 27 to 28 Feb 2018. Bacterial cells on the leaf surfaces might have been emitted through mechanical momentum of the raindrop impaction according to Joung et al. (2017) and/or might be related to a "postrain" bioaerosol enhancement according to Huffman et al. (2013). While the initial results presented here emphasize such potential links between the variability in bioaerosol concentrations and meteorological environmental parameters (which are speculative so far), the statistical basis of these initial FISH results is too small to constrain these relationships. Accordingly, an investigation of bioaerosol

\footnotetext{
${ }^{2}$ In fact, we refrain from interpreting $N_{\mathrm{ARC}}$ in great detail in this work due to the low statistics. Furthermore, the probe ARCH915 used here was found to hybridize with some Bacteria, which could lead to false-positive signals.
} 
https://doi.org/10.5194/bg-2020-469

Preprint. Discussion started: 18 January 2021

(c) Author(s) 2021. CC BY 4.0 License.

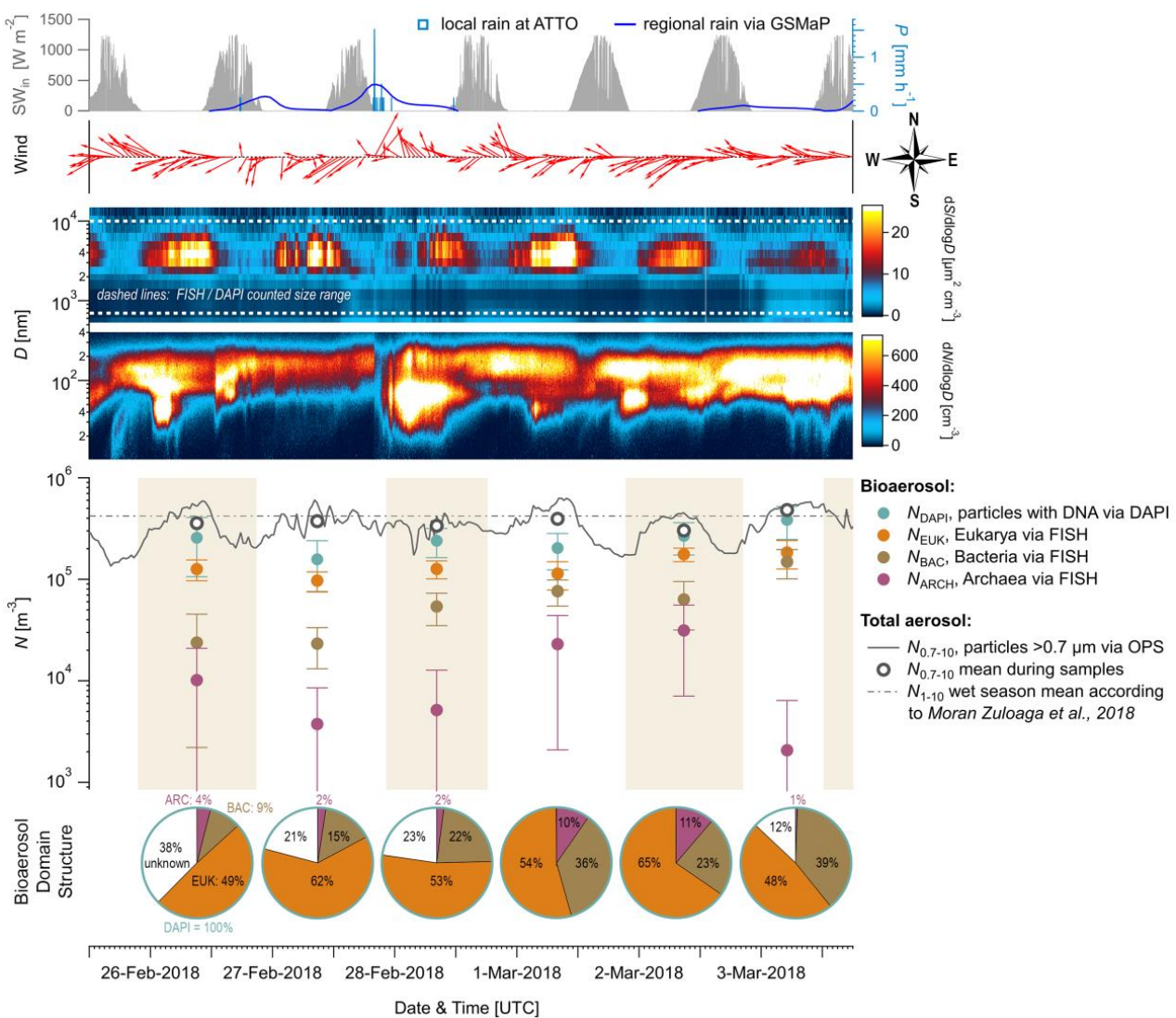

5 Figure 2. Time series of aerosol number concentrations and complementary aerosol and meteorological data at $60 \mathrm{~m}$ height, observed over six days during the wet season 2018. From top to bottom: i) meteorological data including incoming solar radiation ( $S W_{\text {in, }}$ grey shaded), precipitation rates ( $P$, blue curve and bars), and wind vectors (red arrows) ii) contour plots displaying total aerosol number size distributions obtained by a Scanning Mobility Particle Sizer (0.01 to $0.4 \mu \mathrm{m}$ ) and an Optical Particle Sizer $(0.5$ to $10 \mu \mathrm{m})$ iii) bioaerosol number concentrations at the domain level from FISH and DAPI staining (markers as mean and error bars as one standard deviation) with shaded areas as filter sampling periods (each approx. $23 \mathrm{~h}$ ), and iv) pie charts showing daily bioaerosol mixture based on number concentrations at the domain level.

In addition to intact airborne cells, bioaerosol definitions also include biological fragments (Després et al., 2012). These fragments - a complex mixture of biological material in a continuum of degradation states, e.g., from mechanical fragmentation, cell rupture, or cytosol release - can be of 
significant atmospheric relevance as they may comprise (high) ice activity or allergenic potential (Šantl-Temkiv et al., 2015; Steiner et al., 2015; Reinmuth-Selzle et al., 2017). However, a direct analysis of these fragments is often notoriously difficult because of their morphologically and biologically undefined state. Both, the DAPI and FISH quantifications predominantly target intact cells, since

5 upon cell rupture or damage the contained nucleic acids might be released and degraded. Therefore, the ratio of $N_{\text {DAPI }}$ vs. $N_{0.7-10}$ provides a valuable estimate of the presumably intact cell fraction vs. the fraction of fragments within the size range from 0.7 to $10 \mu \mathrm{m}$ of the Amazonian bioaerosol population. This estimate relies on the assumption that under unperturbed wet season conditions the vast majority of coarse mode particles originates more or less directly from primary emissions of the rain forest (compare Moran-Zuloaga et al., 2018; Pöhlker et al., 2018). This assumption is justified here since other potential coarse mode sources (i.e., Saharan dust, Atlantic sea salt, and ash from biomass burning) can be largely excluded during the sampling period. On average, intact cells accounted for the majority of coarse mode particles with $N_{\text {DAPI }} / N_{0.7-10}$ values of $\sim 70 \%$, being in good agreement with previous studies (Table 2 and S3). Accordingly, we obtained $\sim 30 \%$ on average as an upper limit estimate for the fraction of fragments and degraded biological material in this size range. The estimated concentration $\left(3-19 \cdot 10^{4} \mathrm{~m}^{-3}\right)$ and fraction $(12-58 \%)$ of fragments is quite variable, which points at interesting open questions for follow-up studies on potential degradation pathways in the Amazonian bioaerosol cycling.

Table 2. Mean diel aerosol number concentrations at $60 \mathrm{~m}$ height obtained by an optical particle sizer (OPS) and by bioaerosol staining with DAPI (avg $\pm \mathrm{sd}$ ). The fraction of DAPI-stained particles in relation to total aerosol numbers in the same size range provides an estimation of presumably intact cells versus degraded biological material.

\begin{tabular}{lccc} 
sample & $\begin{array}{c}\text { OPS } \\
{\left[\cdot 10^{-4} \mathrm{~m}^{-3}\right]}\end{array}$ & $\begin{array}{c}\text { DAPI } \\
{\left[\cdot 10^{-4} \mathrm{~m}^{-3}\right]}\end{array}$ & $\begin{array}{c}\text { fraction } \\
\text { DAPI/OPS }\end{array}$ \\
\hline day 1 & $36 \pm 13$ & $26 \pm 15$ & 0.72 \\
day 2 & $37 \pm 9.7$ & $16 \pm 8.2$ & 0.42 \\
day 3 & $34 \pm 5.9$ & $24 \pm 7.7$ & 0.71 \\
day 4 & $39 \pm 14$ & $20 \pm 8.0$ & 0.52 \\
day 5 & $30 \pm 10$ & $27 \pm 9.4$ & 0.88 \\
day 6 & $48 \pm 9.1$ & $38 \pm 14$ & 0.80 \\
\hline avg (1-6) & $37 \pm 10$ & $25 \pm 10$ & 0.67
\end{tabular}


Furthermore, we investigated the bioaerosol variability with height across the lower $325 \mathrm{~m}$ of the boundary layer to assess the gradients of specific organism classes in this particularly important part of the atmospheric vertical structure. As expected, the vertical profiles displayed in Figure 3 show a general and rather steep decrease in the average cell concentrations ranging from $N_{\text {DAPI }}=53 \cdot 10^{4} \mathrm{~m}^{-3}$

5 at $5 \mathrm{~m}$, via $25 \cdot 10^{4} \mathrm{~m}^{-3}$ at $60 \mathrm{~m}$ (a $52 \%$ reduction) to $12 \cdot 10^{4} \mathrm{~m}^{-3}$ at $325 \mathrm{~m} \mathrm{(77 \%} \mathrm{reduction} \mathrm{compared}$ to $5 \mathrm{~m}$ ). The eukaryotic cell concentration, $N_{\mathrm{EUK}}$, shows a similarly steep decrease in its profile. For bacterial cells, however, we found a less steep vertical trend with similar concentrations at $5 \mathrm{~m}$ and 60 $\mathrm{m}\left(\sim 7.1 \cdot 10^{4} \mathrm{~m}^{-3}\right.$ vs. $\left.6.5 \cdot 10^{4} \mathrm{~m}^{-3}\right)$, followed by a $54 \%$ reduction from $60 \mathrm{~m}$ to $325 \mathrm{~m}\left(\sim 3 \cdot 10^{4} \mathrm{~m}^{-3}\right)$. For Archaea, the highest concentrations were found at $60 \mathrm{~m}$, although the low concentrations and counting statistics do not allow robust conclusions on the vertical profile of this organism class. All concentrations are summarized in Table 1. As an additional aspect, we also calculated airborne DNA mass concentrations based on aforementioned FISH number concentrations in combination with typical mean genome sizes of fungi, Bacteria and Archaea. ${ }^{3}$ Such results on atmospheric DNA concentrations are sparse and typically based on photometric DNA quantification after extraction from aerosol filters. We obtained average airborne DNA mass concentrations of $11.9 \mathrm{ng} \mathrm{m}^{-3}$ at $5 \mathrm{~m}, 4.5 \mathrm{ng} \mathrm{m}^{-3}$ at $60 \mathrm{~m}$, and $1.2 \mathrm{ng} \mathrm{m}^{-3}$ at $325 \mathrm{~m}$ (Table S2). In general, these results are comparable to studies conducted at an urban site yielding $7 \mathrm{ng} \mathrm{m}^{-3}$ (Després et al., 2007), a boreal forest yielding $8.60 \pm 11.1 \mathrm{ng} \mathrm{m}^{-3}$ (Helin et al., 2017), and the tropical region of Singapore yielding 0.69 to $6.9 \mathrm{ng} \mathrm{m}^{-3}$ (Gusareva et al., 2019). The Amazonian DNA concentrations presented here can be considered as a

20 lower limit (for details, see appendix). Our data suggests that the Amazonian air microbiome to host larger quantities of DNA mass concentration, than reported for other ecosystems before.

The clear difference in the $N_{\text {EUK }}$ vs. $N_{\text {BAC }}$ profile structures might be due to different distribution of the organism sources inside and below the canopy space (i.e., biofilms on leaves according to Morris et al., 1997 vs. pronounced fungal spore emission at the ground according to Elbert et al., 2007 and

25 Löbs et al., 2020). Another reason might be the different sedimentation velocities and, thus, airborne residence times, due to widely different particle mass. Further, please note that the fraction of unclassified particles increased substantially towards $325 \mathrm{~m}$, which may be related to enhanced cell aging due to radiation and/or atmospheric oxidation upon upward transport. Typical cloud base heights in the central Amazon range between 500 and 1500 m (O. Lauer, personal communication, 2020), which 30 is substantially higher than the $325 \mathrm{~m}$ sampling height used here. Still, the measured values for $N_{\mathrm{EUK}}$, $N_{\text {BAC }}, N_{\text {ARC }}$, and $N_{\text {DAPI }}$ at $325 \mathrm{~m}$ can serve as a solid upper limit estimate for cell concentrations being convectively lifted to cloud base. This estimate may be of value for cloud microphysical process studies in combination with Amazonian IN observations and parameterizations (e.g., Prenni et al., 2009; Schrod et al., 2020).

\footnotetext{
${ }^{3}$ With the chosen approach, this quantification exclusively accounts for intracellular DNA and omits the fraction of extracellular DNA.
} 


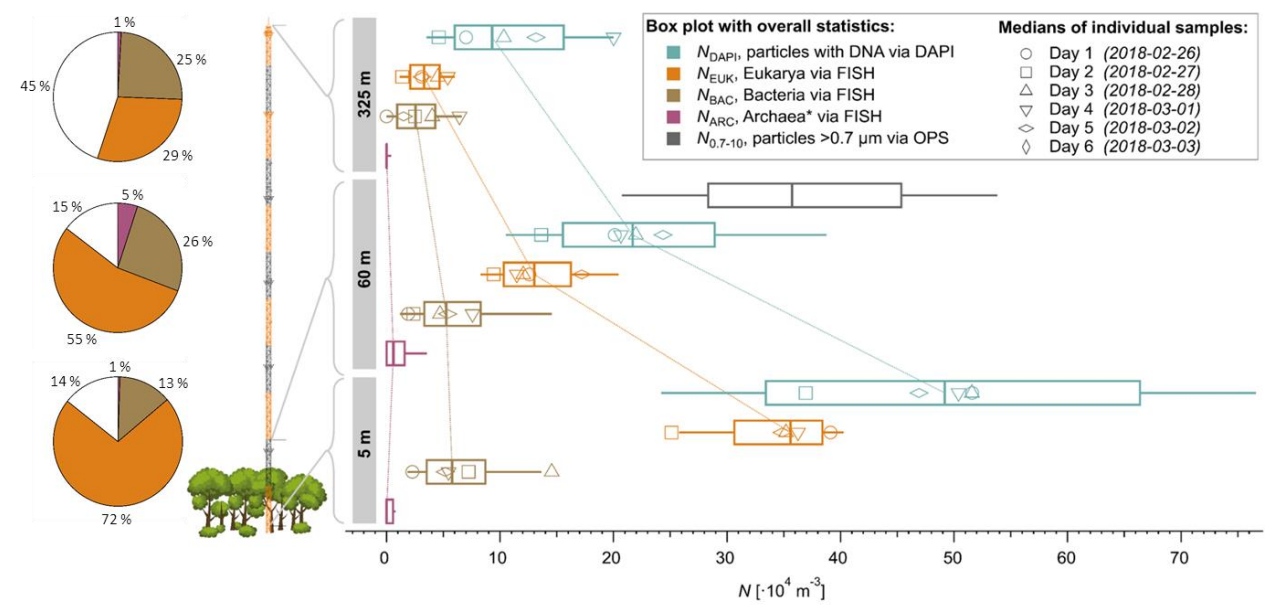

Figure 3. Height profiles of aerosol number concentrations observed at $5 \mathrm{~m}, 60 \mathrm{~m}$, and $325 \mathrm{~m}$ above ground at the ATTO-tower. The median concentrations of all daily samples are displayed as vertical box-whisker plots with 25 and 75 quartiles as box, and 10 and 90 percentiles as whiskers. Daily median values are shown as markers according to the legend. Bioaerosols were quantified with FISH as well as DAPI staining. The total aerosol number concentration at $60 \mathrm{~m}$ was determined by an optical particle sizer (OPS) in the corresponding size range.

Finally, the microscopic enumeration of cells after staining also provides qualitative insights into the mixing state of the Amazonian bioaerosol population, which is an important aspect of the Amazonian bioaerosol cycling (Pöschl et al., 2010). Figure 4 shows typical fluorescence images after DAPI and FISH staining obtained from the three different sampling heights. Figure $4 \mathrm{G}$ and $\mathrm{H}$ show an example of a cell agglomerate comprising multiple eukaryotic and bacterial cells. The vast majority of cells, however, was observed as separated cells, which suggests that under the given wet season conditions the bioaerosol components are largely externally mixed. Another (qualitative) observation worth noting is a decrease of average cell size with height (i.e., more larger particles with $>2 \mu \mathrm{m}$ at 5 and $60 \mathrm{~m}$ relative to $325 \mathrm{~m}$ ). Several of the large cells could be identified as fungal and fern spores, based on morphological criteria. An enrichment of larger particles at the lower heights is in accordance with their higher sedimentation tendency and lower atmospheric residence times. The decreasing size with height corresponds well to the increasing fraction of bacterial cells, which are typically smaller than eukaryotic cells. A systematic retrieval of bioaerosol number size distributions from the FISH micrographs to investigate such trends in details, however, is rather challenging and thus will be subject of a follow-up study. 
https://doi.org/10.5194/bg-2020-469

Preprint. Discussion started: 18 January 2021

(c) Author(s) 2021. CC BY 4.0 License.
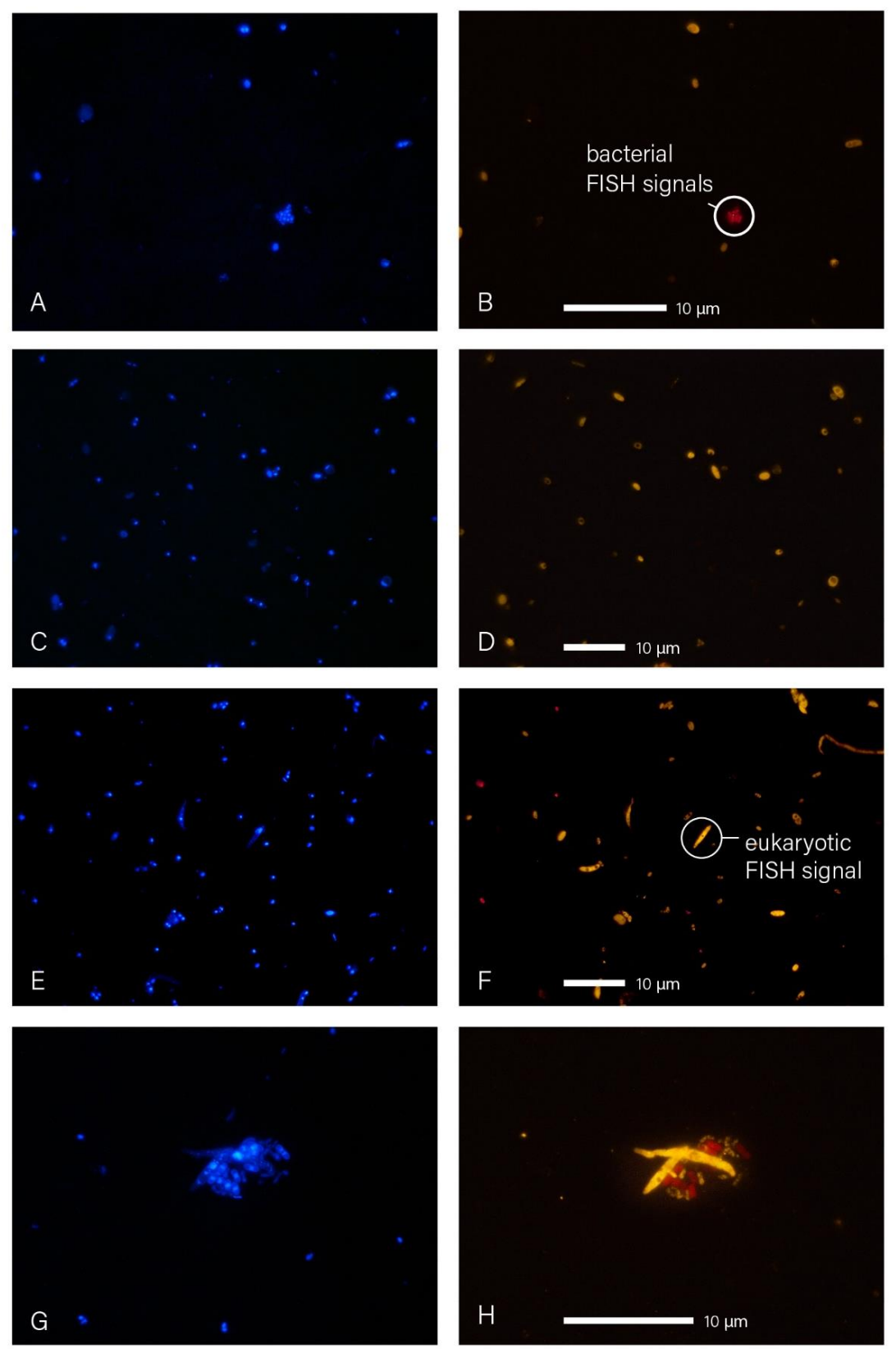

Figure 4. Microscopic images of fluorescence signals after DNA staining with DAPI (left panel, blue) and FISH (right panel, eukaryotes in orange and bacteria in red). Filter samples displayed here were collected at $325 \mathrm{~m}(\mathrm{~A}, \mathrm{~B}), 60 \mathrm{~m}(\mathrm{C}, \mathrm{D})$, and $5 \mathrm{~m}(\mathrm{E}, \mathrm{F}, \mathrm{G}, \mathrm{H})$. Particle agglomerates, as shown in $\mathrm{G}$ and

$5 \mathrm{H}$, we found rather rarely. Agglomerate here shows cluster of fungal spores and bacterial cells. 


\section{Conclusions}

Our study showed that FISH has great analytical potential in bioaerosol analysis. It combines bioaerosol identification and quantification and, thus, provides insights into the concentration levels and spatiotemporal variability of specific and clearly defined organism groups within the bioaerosol population. We investigated the Amazonian bioaerosols on domain level by quantifying eukaryotic, bacterial, and archaeal cells as well as the overall concentrations of airborne cells as a function of time and height within and above the forest canopy. The results characterize bioaerosols during clean wet-season conditions in the Amazon under the predominance of local emissions from the primary rain forest. Eukarya (29-72\%) and Bacteria (13-26\%) dominated the bioaerosol population and variability, whereas Archaea (0,5- $5 \%$ ) played numerically only a minor role. On average $\sim 70 \%$ of the coarse mode particles (i.e., $0.7-10 \mu \mathrm{m})$ were attributed to presumably intact cells whereas the remaining $\sim 30 \%$ can be regarded as an upper limit estimate for biological fragments and degenerated biological material in this size fraction under the given conditions. The bioaerosol concentrations decreased substantially with height with $\sim 2$ times less Bacteria and even $\sim 10$ times less Eukaryotes at $325 \mathrm{~m}$ than under the canopy. This emphasizes the importance of the sampling height as a variable for bioaerosol observations in the Amazon. The different shapes of the bacterial vs. eukaryotic concentration profiles may be attributed to different source locations in and below the canopy and/or differences in aerodynamic mobility of the cells upon vertical transport. Overall, the results of this study greatly extend the knowledge on the life cycle of the Amazonian aerosols and provide a solid experimental basis for

20 model investigations of bioaerosol-related processes, such as the role of biological ice nuclei or giant cloud condensation nuclei in cloud microphysics and potential bio-precipitation cycling.

Pronounced diurnal patterns with a maximum of coarse mode particle abundance during the night represent a characteristic feature of Amazonian aerosol cycling (Figure 2). The current study demonstrates that a dedicated FISH analysis with separated day vs. night sampling promises to resolve and quantify the organism classes that constitute the diurnal pattern. This further relates to the open question on the main meteorological drivers for bioaerosol emissions in the rain forest ecosystem. For this purpose, a broader statistical basis of FISH results along with meteorological observations is needed. Essential for microphysical bioaerosol analyses is a retrieval of the number size distributions from the DAPI and FISH data sets. Fluxes of specific organism classes from the forest could potentially be determined with a dedicated FISH sampling during periods of strong convection. In addition, the wet season characterization presented here requires a complementary dry season sampling to resolve potential seasonal differences in the bioaerosol abundance and mixture. Finally, the taxonomic resolution of this study operates exclusively on domain level. Future studies should use the analytical potential of FISH by targeting organism classes on lower taxonomic levels (e.g., theoretically down to species level). This is of particular interest in terms of differences in IN activity influencing the formation of clouds. In a bigger picture, we envision that dedicated FISH studies may be conducted in close relation to cloud microphysical process studies. Targeted bioaerosol characterizations during periods of 
https://doi.org/10.5194/bg-2020-469

Preprint. Discussion started: 18 January 2021

(C) Author(s) 2021. CC BY 4.0 License.

climate extremes, such as El Niño-related droughts in the Amazon, would be of great importance to study the response and resilience of the bioaerosol population in the Amazon under warmer and presumably drier climatic conditions in the future. 


\section{Appendix: Materials and Methods}

Measurement location: The Amazon Tall Tower Observatory:

The Amazon Tall Tower Observatory is a research site located in the Uatumã Sustainable Development Reserve, Amazonas State, Brazil (Andreae et al., 2015). It comprises several ground-based containers and three towers of different heights ( $80 \mathrm{~m}$ height: 'Triangular mast' and 'Walk-up tower'; 325 $\mathrm{m}$ height: 'Tall tower')"equipped with state-of-the-art instrumentation to analyze biosphere-atmosphere exchange processes in this remote continental location. The forest ecosystem is driven by alternating wet and dry seasons inducing conditions that temporarily resemble a pre-industrial and thus pristine state. Hundreds of square kilometers of untouched primary forest surround the research station, forming its biogeochemical footprint region (Pöhlker et al., 2019). Further information on the sampling location can be found in the supplement.

\section{Aerosol sampling at ATTO}

This study focuses on seven aerosol samples, collected during the wet season from 25 Feb 2018 to 3

15 Mar 2018, with an approximate sampling duration of $23 \mathrm{~h}$ each. Samples at $5 \mathrm{~m}$ and $60 \mathrm{~m}$ height were collected at the triangular mast, those at $325 \mathrm{~m}$ at the tall tower. At $5 \mathrm{~m}$, the filter holder was connected directly to a total suspended particle (TSP) inlet. At $60 \mathrm{~m}$ and $325 \mathrm{~m}$ height, filter holders were mounted in a ground-based container and connected to a TSP inlet via stainless steel inlet lines. Aerosols were filtered onto white polycarbonate membranes (Isopore PC Membrane, $0.2 \mu \mathrm{m}$ pore size, 47 mm diameter, GTTP04700, Merck, Darmstadt, Germany) by applying a vacuum. Filters were autoclaved at $121^{\circ} \mathrm{C}$ and $220 \mathrm{kPa}$ for $15 \mathrm{~min}$ before use. The sample air flow rate was set to $9 \mathrm{lpm}$ by a digital mass flow controller (D-6341-FGD-22-AV-99-D-S-DR, Wagner Mess- und Regeltechnik, Offenbach am Main, Germany) installed between the pump (N840.3FT.18, KNF Neuberger, Freiburg im Breisgau, Germany) and a custom-made filter holder.

\section{Complementary online measurements at ATTO}

During filter sampling, three instruments measured aerosol number concentrations in parallel at $60 \mathrm{~m}$ height: an Optical Particle Sizer (OPS, model 3330, size range 0.3-10 $\mu \mathrm{m}$, TSI Inc., Shoreview, MN, USA) and a Scanning Mobility Particle Sizer (SMPS, classifier 3080, detector 3722, DMA 3081, size range: 0.01-0.42 $\mu \mathrm{m}$, TSI Inc., Shoreview, USA), both detected aerosols in a size resolved manner, and a Condensation Particle Counter (CPC, model 5412, Grimm Aerosol, Ainring, Germany) measured total aerosol concentrations. Detailed information on OPS, SMPS, and CPC measurements can be found in Andreae et al. (2015) and Moran-Zuloaga et al. (2018). Stained bioaerosols could only be detected and identified as such by microscopy if their diameter was $\sim 0.7 \mu \mathrm{m}$ or larger. For a comparison between $N_{\text {FISH }}$ and total aerosol numbers, only OPS data detected in the according channels was considered (0.74-10 $\left.\mu \mathrm{m}, N_{0.7-10}\right)$. Several sensors monitored meteorological conditions at ATTO such as incoming shortwave radiation (Pyranometer, CMP21, Kipp \& Zonen, Netherlands) and rainfall 
(Rain gauge, TB4, Hydrological Services Pty. Ltd., Australia). Further information on micrometeorological sensors and instrumentation at ATTO can be found in Andreae et al. (2015).

\section{Fluorescence in Situ Hybridization}

5 Several previous studies containing fluorescence in situ hybridization (FISH) protocols were considered in terms of buffer ingredients, incubation times, and further details, to obtain reliable results in bioaerosol analysis. Original references can be found in Glöckner et al. (1996, 1999), Pernthaler et al. (2004), Fuchs et al. (2007), and Schmidt et al. (2012). The chemicals used for fixation, permeabilization, hybridization, staining, and mounting are listed in the supplement (Table S4). Best results were obtained by applying the following procedure: Directly after sampling, bioaerosols on the filters were fixed by an incubation in a freshly prepared solution of $2 \%$ Formaldehyde in phosphate buffered saline (PBS). For this purpose, filters were inserted into glass filtration towers (107003970, Sartorius, Göttingen, Germany) and covered with $\sim 15 \mathrm{~mL}$ of the solution. The liquid was removed after $1 \mathrm{~h}$ at $28^{\circ} \mathrm{C}$ ambient temperature by applying a gentle vacuum. Subsequently, filters were flushed by covering them with $20 \mathrm{~mL}$ deionized water (MQ water) and applying vacuum again. The same procedure was repeated with $20 \mathrm{~mL}$ Ethanol $70 \%$. Filters were air-dried and stored in Analyslide petri dishes (7231, Pall corporation, New York, USA) at $-20^{\circ} \mathrm{C}$ in the freezer. Filters were transported to Germany frozen and stored in the freezer at $-20^{\circ} \mathrm{C}$ until further processing.

The filters were then cut into sections and numbered with a pencil at room temperature. For each sample, one fixed, cut and numbered filter section was directly mounted in Citifluor AF1 (Citifluor Ltd., Canterbury, UK) containing $4 \mu \mathrm{g} \mathrm{mL}^{-1}$ DAPI (4',6-Diamidin-2-phenylindol, Serva, Heidelberg, Germany) for total cell number detection.

To prevent cell loss during FISH, filter sections were covered with a thin layer of low gelling point agarose ( $0.2 \%$ in MQ water). Cell wall permeabilization by means of incubation in lysozyme solution (10 mg mL ${ }^{-1}$; 60 min for EUK516 and 45 min for EUB338-I-III (EUB-mix), ARCH915, and NON338) and achromopeptidase solution (60 $\mathrm{U} \mathrm{ml}^{-1}, 20 \mathrm{~min}$ for EUB338-mix, ARCH915, and 338), both at $37^{\circ} \mathrm{C}$, enabled the entrance of oligonucleotide probes during hybridization. To remove all enzymes, filter sections were washed in excess MQ water. Subsequently, the filter sections were incubated in $30 \mu \mathrm{L}$ hybridization buffer $(900 \mathrm{mM} \mathrm{NaCl}, 20 \mathrm{mM}$ Tris/ $\mathrm{HCl}, 1 \%$ blocking reagent, $0,01 \%$

30 SDS, and formamide depending on probe) containing $2 \mu \mathrm{L}$ probe working solution $\left(8.4 \mathrm{pmol}^{-1}\right)$ at $46^{\circ} \mathrm{C}$ for $120 \mathrm{~min}$. Oligonucleotide probes targeting bacterial, eukaryotic, and archaeal cells were used. The probe NON338 served as negative control. Probe sequences, labels, and the respective formamide concentrations are presented in Table A1. After hybridization, filter sections were directly transferred into $50 \mathrm{~mL}$ preheated washing buffer (0.9 M (EUK516) or $0.08 \mathrm{M}$ (EUB338-mix, 
filter sections were gently inverted when the incubation started and ended. Subsequently, filter sections were rinsed in a Petri dish containing MQ water and a second Petri dish containing $70 \%$ ethanol. Filter sections were dried on Kim wipes at room temperature for 15-30 min. Dry filter sections were mounted in Citifluor AF1 containing $4 \mu \mathrm{g} \mathrm{mL}^{-1}$ DAPI.

5

\section{Epifluorescent microscopic enumeration and bioaerosol projection}

Filter sections were inspected with a Nikon Ti2-E inverse epifluorescence microscope (Nikon, Microscope Solutions, Minato, Japan) at 600x magnification (objective: Apo Lamda S 60x Oil with 1.4 numerical aperture and a 10x widefield ocular). Epifluorescence filter cubes were chosen according to

10 the fluorescent dye properties as summarized in Table A1. Fluorescence signals deriving from DAPI staining or FISH were counted manually using an ocular grid (Zeder et al., 2011). One person examined all filter samples for FISH and DAPI signals to ensure consistent counting procedure. As in previous studies, the examiner rested regularly to avoid eye fatigue leading to decreasing signal detection. FISH and DAPI signals were detected as such, by taking their color, fluorescence intensity, size, shape, and surface structure into account. Raw counts were documented with help of a mechanical counter. In a first step, filter sections that were embedded in a mix of Citifluor and DAPI were analyzed. The atmospheric number concentrations of bioaerosols that were stained with the DNA-dye were calculated by extrapolating DAPI raw counts with respect to the grid size, covered filter area and sampled air volume.

$$
N_{\text {DAPI }}=\frac{\mathrm{N}_{\text {grid }} \cdot \mathrm{A}_{\mathrm{f}}}{\mathrm{A}_{\text {grid }} \cdot V_{\text {air }}}
$$

$N_{\text {DAPI }}=$ atmospheric bioaerosol number concentration stained with DAPI $\left[\mathrm{m}^{-3}\right]$

$\mathrm{N}_{\text {grid }}=$ number of DAPI stained cells counted per grid

$\mathrm{A}_{\mathrm{f}}=$ area filter $\left[\mathrm{mm}^{2}\right]$

$\mathrm{A}_{\text {grid }}=$ area grid $\left[\mathrm{mm}^{2}\right]$

$\mathrm{V}_{\text {air }}=$ sampled air volume $\left[\mathrm{m}^{3}\right]$

Afterwards, filter sections treated with the FISH technique were inspected. The FISH signals were enumerated first $\left(N_{\mathrm{FISH}}\right)$, and consecutively DAPI counterstaining signals were quantified in the same field of view to avoid bleaching of the former. Ratios of hybridized bioaerosols were calculated and multiplied with the bioaerosol number concentrations obtained by DAPI staining only. To achieve robust statistics at least 500 DAPI stained cells per filter sample and probe were inspected, often more than 1000 were counted. According to Pernthaler et al. (2003) this reduces the counting error to $<5 \%$. Raw counts of hybridized and DAPI stained cells for each filter sample are presented in the supple- 
https://doi.org/10.5194/bg-2020-469

Preprint. Discussion started: 18 January 2021

(c) Author(s) 2021. CC BY 4.0 License.

\section{Quantification of atmospheric DNA concentration}

Airborne DNA mass was calculated by multiplication of mean bioaerosol numbers obtained by FISH with the typical DNA mass of a bacterial, eukaryotic, or archaeal cell.

$$
m_{\mathrm{DNA}}=\frac{N_{F I S H} \cdot \mathrm{bp} \cdot 609.7 \mathrm{~g} / \mathrm{mol}}{N_{A}}
$$

$m_{\mathrm{DNA}}=$ airborne DNA mass $\left[\mathrm{g} \mathrm{m}^{-3}\right]$

$N_{\text {FISH }}=$ bioaerosol number concentration obtained by FISH $\left[1 \mathrm{~m}^{-3}\right]$

$\mathrm{bp}=$ genome size [base pair cell ${ }^{-1}$ ]

$10 \quad 609.7 \mathrm{~g} \mathrm{~mol}^{-1}=$ average mass of a base pair in bound form (see appendix)

$N_{\mathrm{A}}=$ Avogadro constant

The genome size of Bacteria was defined as $4 \mathrm{Mb}$, as found in the NCBI data base for airborne Bacteria present in the Amazonian air microbiome (e.g. Proteobacteria, Actinobacteria, Souza et al.,

15 2019). Archaeal genome size was defined as $4 \mathrm{Mb}$ as well (Landenmark et al., 2015). The genome size of fungi was used as a representative value for Eukaryotes, since coarse mode bioaerosols in the Amazon were reported to mainly consist of fungal spores (Graham et al., 2003; Huffman et al., 2012). As these genome sizes are several orders of magnitude smaller compared to those of higher plants, we consider the here presented airborne DNA mass obtained this way as a lower limit for the Amazon

20 forest bioaerosol. In NCBI the typical genome size for basidiomycetes and ascomycetes is indicated as $30 \mathrm{Mb}$. 
Table A1: Technical details of rRNA targeting probes and corresponding microscopic filters (excitation, dicroic mirror, and emission) used for FISH. As described in Daims et al. (1999), a mixture of EUB338 I, II, and III (referred to as EUB-mix) was applied for identification of Bacteria. By use of ARCH915, Archaea were identified and EUK516 was applied to hybridize Eukarya. NON338 served as negative control. DAPI stains all particles containing DNA by attaching preferably to adenine and thymine rich sequences. For our experiments, fluorescent labels in the reddish wavelength range were chosen to avoid overlap with the autofluorescence of bioaerosols which is typically strong in the green wavelength range (Pöhlker et al., 2012).

\begin{tabular}{|c|c|c|c|c|c|c|c|}
\hline probe/stain & sequence/ target & label & $\begin{array}{l}\text { form- } \\
\text { amide }\end{array}$ & reference & exc. & $\begin{array}{l}\text { dic. } \\
\text { mirror }\end{array}$ & em. \\
\hline$\overline{\text { EUB338I }}$ & GCTGCCTCCCGTAGGAGT & 4x ATTO594 & $35 \%$ & Amann et al. 1990 & & & \\
\hline EUB338II & GCAGCCACCCGTAGGTGT & 4x ATTO594 & $35 \%$ & Daims et al. 1999 & & & \\
\hline EUB338III & GCTGCCACCCGTAGGTGT & 4x ATTO594 & $35 \%$ & Daims et al. 1999 & $562 / 40$ & 593 & $624 / 40$ \\
\hline NON338 & ACTCCTACGGGAGGCAGC & 4x ATTO594 & $35 \%$ & Wallner et al. 1993 & & & \\
\hline ARCH915 & GTGCTCCCCCGCCAATTCCT & 1x ATTO594 & $35 \%$ & Stahl and Amann, 1991 & & & \\
\hline EUK516 & ACCAGACTTGCCCTCC & 1x ATTO542 & $0 \%$ & Amann et al. 1990 & $545 / 25$ & 565 & $605 / 70$ \\
\hline DAPI & DNA & & & & $387 / 11$ & 400 & $409 \mathrm{LP}$ \\
\hline
\end{tabular}


Data availability. Online ATTO data can be found in the ATTO data portal under https://www.attodata.org/ (ATTO, 2020). All essential results from FISH and DAPI staining are provided in the main text and supplementary tables. For data requests beyond the available data, please refer to the corresponding authors.

5 Author contributions. MP and CP developed the research and the experiments. MP conducted the sampling, the sample analysis and manuscript preparation with contributions from all co-authors. FD, LAK, MAF, ACA supported the sample collection, data acquisition at the ATTO site, and online data analysis. IHA and JW supported in the laboratory filter analysis. BMF provided advice and guidance for the adaptation of FISH protocols for bioaerosol analysis. DW and TK developed data analysis routines. MOA, JK, BW, PA, and ET provided valuable ideas to the data analysis and interpretation. WE contributed to the literature research and comparison with earlier studies. CP and UP supervised the work. All the authors contributed to the interpretation of the results and writing of the paper.

Competing interests. The authors declare that they have no conflict of interest.

Acknowledgements. This work has been supported by the Max Planck Society (MPG) and the Max

Planck Graduate Center with the Johannes Gutenberg University Mainz (MPGC). For the operation of the ATTO site, we acknowledge the support by the German Federal Ministry of Education and Research (BMBF contract nos. 01LB1001A and 01LK1602B) and the Brazilian Ministério da Ciência, Tecnologia e Inovação (MCTI/FINEP contract 01.11.01248.00) as well as the Amazon State University (UEA), FAPEAM, LBA/INPA, and SDS/CEUC/RDS-Uatumã. This paper contains results of research conducted under the Technical/Scientific Cooperation Agreement between the National Institute for Amazonian Research, the State University of Amazonas, and the Max-Planck-Gesellschaft e.V.; the opinions expressed are the entire responsibility of the authors and not of the participating institutions. We acknowledge the support by the Instituto Nacional de Pesquisas da Amazônia (INPA). We would like to thank Reiner Ditz, Stefan Wolff, Susan Trumbore, Alberto Quesada, Hermes Braga Xavier, Andrew Crozier, Nagib Alberto de Castro Souza, Thiago de Lima Xavier, Thomas Disper, Josué Ferreira de Souza, Feliciano de Souza Coelho, Antonio Huxley Melo Nascimento, André Luiz Matos, Elton Mendes da Silva, Björn Nillius, Antonio Ocimar Manzi, Roberta Pereira de Souza, Wallace Rabelo Costa Amauri Rodriguês Perreira, Steffen Schmidt, Uwe Schulz, Bruno Takeshi, and Adir Vasconcelos Brandão for technical, logistical, and scientific support within the ATTO project. We thank Annemarie Zahn for graphical support with figure design. We thank especially Jörg Wulf, Andreas Ellrott, Stefan Thiele, and Rudolf Amann for substantial scientific and technical support with the FISH analysis. Moreover, we thank Jan-David Förster, Viviane Després, Janine FröhlichNowoisky, Thomas Behrendt, Anna Kunert, Ovid Krüger, Oliver Lauer, Bruna A. Holanda, Matthias Sörgel, and Luiz A. T. Machado for scientific support and stimulating discussions. 


\section{References}

Amann, R. I., Krumholz, L., and Stahl, D. A.: Fluorescent-oligonucleotide probing of whole cells for determinative, phylogenetic, and environmental studies in microbiology, Journal of Bacteriology, 172, 762-770, 1990.

5 Amann, R., and Fuchs, B. M.: Single-cell identification in microbial communities by improved fluorescence in situ hybridization techniques, Nature Reviews Microbiology, 6, 339-348, 2008.

Andreae, M. O., and Crutzen, P. J.: Atmospheric aerosols: Biogeochemical sources and role in atmospheric chemistry, Science, 276, 1052-1058, 1997.

Andreae, M. O.: Aerosols before pollution, Science, 315, 50-51, 10.1126/science.1136529, 2007.

10 Andreae, M., Acevedo, O., Araùjo, A., Artaxo, P., Barbosa, C., Barbosa, H., Brito, J., Carbone, S., Chi, X., and Cintra, B.: The Amazon Tall Tower Observatory (ATTO): overview of pilot measurements on ecosystem ecology, meteorology, trace gases, and aerosols, Atmospheric Chemistry and Physics, 15, 10723-10776, 2015.

Artaxo, P., Hansson, H. C., Andreae, M. O., Bäck, J., Alves, E. G., Barbosa, H. M. J., Bender, F., Bourtsoukidis, E., Carbone, S., Chi, J., Decesari, S., Després, V. R., Ditas, F., Ezhova, E., Fuzzi, S., Hasselquist, N. J.,

15 Heintzenberg, J., Holanda, B. A., Guenther, A., Hakola, H., Heikkinen, L., Kerminen, V. M., Kontkanen, J., Krejci, R., Kulmala, M., Lavric, J. V., de Leeuw, G., Lehtipalo, K., Machado, L. A. T., McFiggans, G., Franco, M. A. M., Mohr, C., Morgan, W., Nilsson, M. B., Peichl, M., Petäjä, T., Praß, M., Pöhlker, C., Pöhlker, M. L., Pöschl, U., Von Randow, C., Riipinen, I., Rinne, J., Rizzo, L. V., Rosenfeld, D., Assunção Faus da Silva Dias, M., Sogacheva, L., Stier, P., Swietlicki, E., Sörgel, M., Tunved, P., Virkkula, A., Wang, J., Weber, B., Yáñez-

20 Serrano, A. M., and Zieger, P., Eugene Mikhailov, E., Smith, J.N., Kesselmeier, J.,: Tropical and boreal forests Atmosphere interactions, a review, under revision.

Bonan, G. B.: Forests and climate change: forcings, feedbacks, and the climate benefits of forests, Science, 320 , 1444-1449, 2008.

Burrows, S. M., Butler, T., Jockel, P., Tost, H., Kerkweg, A., Poschl, U., and Lawrence, M. G.: Bacteria in the global atmosphere - Part 2: Modeling of emissions and transport between different ecosystems, Atmospheric Chemistry and Physics, 9, 9281-9297, 2009a.

Burrows, S. M., Elbert, W., Lawrence, M. G., and Poschl, U.: Bacteria in the global atmosphere - Part 1: Review and synthesis of literature data for different ecosystems, Atmospheric Chemistry and Physics, 9, 9263 9280, $2009 b$.

30 Christensen, H., Hansen, M., and Sørensen, J.: Counting and size classification of active soil bacteria by fluorescence in situ hybridization with an rRNA oligonucleotide probe, Applied and Environmental Microbiology, 65, 1753-1761, 1999.

Daims, H., Brühl, A., Amann, R., Schleifer, K.-H., and Wagner, M.: The Domain-specific Probe EUB338 is Insufficient for the Detection of all Bacteria: Development and Evaluation of a more Comprehensive Probe Set, Systematic and Applied Microbiology, 22, 434-444, http://dx.doi.org/10.1016/S0723-2020(99)80053-8, 1999.

Deguillaume, L., Leriche, M., Amato, P., Ariya, P. A., Delort, A. M., Poschl, U., Chaumerliac, N., Bauer, H., Flossmann, A. I., and Morris, C. E.: Microbiology and atmospheric processes: chemical interactions of primary biological aerosols, Biogeosciences, 5, 1073-1084, 2008.

Delort, A.-M., Vaïtilingom, M., Amato, P., Sancelme, M., Parazols, M., Mailhot, G., Laj, P., and Deguillaume,

40 L.: A short overview of the microbial population in clouds: potential roles in atmospheric chemistry and nucleation processes, Atmospheric Research, 98, 249-260, 2010.

DeMott, P. J., Prenni, A. J., Liu, X., Kreidenweis, S. M., Petters, M. D., Twohy, C. H., Richardson, M. S., Eidhammer, T., and Rogers, D. C.: Predicting global atmospheric ice nuclei distributions and their impacts on climate, Proceedings of the National Academy of Sciences of the United States of America, 107, 11217-11222,

45 10.1073/pnas.0910818107, 2010.

Després, V. R., Fröhlich-Nowoisky, J., Klose, M., Conrad, R., Andreae, M. O., and Pöschl, U.: Characterization of primary biogenic aerosol particles in urban, rural, and high-alpine air by DNA sequence and restriction fragment analysis of ribosomal RNA genes, Biogeosciences, 4, 1127-1141, 2007.

Després, V. R., Huffman, J. A., Burrows, S. M., Hoose, C., Safatov, A. S., Buryak, G., Fröhlich-Nowoisky, J.,

50 Elbert, W., Andreae, M. O., Pöschl, U., and Jaenicke, R.: Primary biological aerosol particles in the atmosphere: a review, Tellus B, 64, 1-58, 10.3402/tellusb.v64i0.15598, 2012. 
Fröhlich-Nowoisky, J., C. J. Kampf, B. Weber, J. A. Huffman, C. Pöhlker, M. O. Andreae, N. Lang-Yona, S. M. Burrows, S. S. Gunthe, W. Elbert, H. Su, P. Hoor, E. Thines, T. Hoffmann, V. R. Després, and U. Pöschl: Bioaerosols in the earth system: climate, health, and ecosystem interactions, Atmospheric Research, 182, 346-376, 2016.

5 Fuchs, B., Pernthaler, J., and Amann, R.: Single cell identification by fluorescence in situ hybridization, Methods for General and Molecular Microbiology, 3, 886-896, 2007.

Gilbert, G. S., and Reynolds, D. R.: Nocturnal fungi: airborne spores in the canopy and understory of a tropical rain forest, Biotropica, 37, 462-464, 2005.

Glöckner, F. O., Amann, R., Alfreider, A., Pernthaler, J., Psenner, R., Trebesius, K., and Schleifer, K.-H.: An in situ hybridization protocol for detection and identification of planktonic bacteria, systematic and applied microbiology, 19, 403-406, http://dx.doi.org/10.1016/S0723-2020(96)80069-5, 1996.

Glöckner, F. O., Fuchs, B. M., and Amann, R.: Bacterioplankton compositions of lakes and oceans: a first comparison based on fluorescence in situ hybridization, Applied and Environmental Microbiology, 65, 3721$3726,1999$.

15 Graham, B., Guyon, P., Maenhaut, W., Taylor, P. E., Ebert, M., Matthias-Maser, S., Mayol-Bracero, O. L., Godoi, R. H. M., Artaxo, P., Meixner, F. X., Moura, M. A. L., Rocha, C., Van Grieken, R., Glovsky, M. M., Flagan, R. C., and Andreae, M. O.: Composition and diurnal variability of the natural Amazonian aerosol, Journal of Geophysical Research-Atmospheres, 108, 4765, 4765, 10.1029/2003jd004049, $2003 \mathrm{a}$.

Graham, B., Guyon, P., Taylor, P. E., Artaxo, P., Maenhaut, W., Glovsky, M. M., Flagan, R. C., and Andreae, M. O.: Organic compounds present in the natural Amazonian aerosol: Characterization by gas chromatographymass spectrometry, Journal of Geophysical Research-Atmospheres, 108, 4766, 10.1029/2003jd003990, 2003 b.

Gusareva, E. S., Acerbi, E., Lau, K. J., Luhung, I., Premkrishnan, B. N., Kolundžija, S., Purbojati, R. W., Wong, A., Houghton, J. N., and Miller, D.: Microbial communities in the tropical air ecosystem follow a precise diel cycle, Proceedings of the National Academy of Sciences, 116, 23299-23308, 2019.

25 Hamilton, D. S., Lee, L. A., Pringle, K. J., Reddington, C. L., Spracklen, D. V., and Carslaw, K. S.: Occurrence of pristine aerosol environments on a polluted planet, Proceedings of the National Academy of Sciences, 111, 18466-18471, 2014.

Harrison, R. M., Jones, A. M., Biggins, P. D. E., Pomeroy, N., Cox, C. S., Kidd, S. P., Hobman, J. L., Brown, N. L., and Beswick, A.: Climate factors influencing bacterial count in background air samples, International

30 Journal of Biometeorology, 49, 167-178, 10.1007/s00484-004-0225-3, 2005.

Huffman, J., Sinha, B., Garland, R., Snee-Pollmann, A., Gunthe, S., Artaxo, P., Martin, S., Andreae, M., and Pöschl, U.: Size distributions and temporal variations of biological aerosol particles in the Amazon rainforest characterized by microscopy and real-time UV-APS fluorescence techniques during AMAZE-08, Atmospheric Chemistry and Physics, 12, 11997-12019, 2012.

35 Huffman, J. A., Prenni, A. J., DeMott, P. J., Pöhlker, C., Mason, R. H., Robinson, N. H., Fröhlich-Nowoisky, J., Tobo, Y., Despres, V. R., Garcia, E., Gochis, D. J., Harris, E., Müller-Germann, I., Ruzene, C., Schmer, B., Sinha, B., Day, D. A., Andreae, M. O., Jimenez, J. L., Gallagher, M., Kreidenweis, S. M., Bertram, A. K., and Pöschl, U.: High concentrations of biological aerosol particles and ice nuclei during and after rain, Atmospheric Chemistry and Physics, 13, 6151-6164, 10.5194/acp-13-6151-2013, 2013.

40 Jaenicke, R.: Abundance of cellular material and proteins in the atmosphere, Science, 308, 73-73, 10.1126/science.1106335, 2005.

Landenmark, H. K., Forgan, D. H., and Cockell, C. S.: An estimate of the total DNA in the biosphere, PLOS Biology, 13, e1002168, 2015.

Mayol, E., Jiménez, M. A., Herndl, G. J., Duarte, C. M., and Arrieta, J. M.: Resolving the abundance and air-sea fluxes of airborne microorganisms in the North Atlantic Ocean, Frontiers in Microbiology, 5, 557, 2014.

Moran-Zuloaga, D., Ditas, F., Walter, D., Saturno, J., Brito, J., Carbone, S., Chi, X., Hrabě de Angelis, I., Baars, H., Godoi, R. H. M., Heese, B., Holanda, B. A., Lavrič, J. V., Martin, S. T., Ming, J., Pöhlker, M. L., Ruckteschler, N., Su, H., Wang, Y., Wang, Q., Wang, Z., Weber, B., Wolff, S., Artaxo, P., Pöschl, U., Andreae, M. O., and Pöhlker, C.: Long-term study on coarse mode aerosols in the Amazon rain forest with the frequent

50 intrusion of Saharan dust plumes, Atmospheric Chemistry and Physics , 18, 10055-10088, 10.5194/acp-1810055-2018, 2018 
Morris, C. E., Monier, J., and Jacques, M.: Methods for observing microbial biofilms directly on leaf surfaces and recovering them for isolation of culturable microorganisms, Applied and Environmental Microbiology, 63, 1570-1576, 1997.

Morris, C. E., Sands, D. C., Bardin, M., Jaenicke, R., Vogel, B., Leyronas, C., Ariya, P. A., and Psenner, R.:

5 Microbiology and atmospheric processes: research challenges concerning the impact of airborne microorganisms on the atmosphere and climate, Biogeosciences, 8, 17-25, 10.5194/bg-8-17-2011, 2011.

Morris, C. E., Conen, F., Alex Huffman, J., Phillips, V., Pöschl, U., and Sands, D. C.: Bioprecipitation: a feedback cycle linking Earth history, ecosystem dynamics and land use through biological ice nucleators in the atmosphere, Global Change Biology, 20, 341-351, 10.1111/gcb.12447, 2014.

10 Moter, A., and Göbel, U. B.: Fluorescence in situ hybridization (FISH) for direct visualization of microorganisms, Journal Microbiological Methods, 41, 85-112, 2000.

Pernthaler, A., Pernthaler, J., Amann, R., Kowalchuk, G., de Bruijn, F., Head, I., Akkermans, A., and van Elsas, J.: Sensitive multi-color fluorescence in situ hybridization for the identification of environmental microorganisms, Molecular Microbial Ecology Manual, Volumes 1 and 2, 711-725, 2004.

15 Pernthaler, J., Pernthaler, A., and Amann, R.: Automated enumeration of groups of marine picoplankton after fluorescence in situ hybridization, Applied and Environmental Microbiology, 69, 2631-2637, 2003.

Pöhlker, C., Huffman, J. A., and Pöschl, U.: Autofluorescence of atmospheric bioaerosols - fluorescent biomolecules and potential interferences, Atmospheric Measurement Techniques, 5, 37-71, 10.5194/amt-5-372012, 2012.

20 Pöhlker, M. L., Ditas, F., Saturno, J., Klimach, T., Hrabě de Angelis, I., Araùjo, A. C., Brito, J., Carbone, S., Cheng, Y., and Chi, X.: Long-term observations of cloud condensation nuclei over the Amazon rain forest-Part 2: Variability and characteristics of biomass burning, long-range transport, and pristine rain forest aerosols, Atmospheric Chemistry and Physics, 18, 10289-10331, 2018.

Pöhlker, C., Walter, D., Paulsen, H., Könemann, T., Rodríguez-Caballero, E., Moran-Zuloaga, D., Brito, J.,

25 Carbone, S., Degrendele, C., and Després, V. R.: Land cover and its transformation in the backward trajectory footprint region of the Amazon Tall Tower Observatory, Atmospheric Chemistry and Physics, 19, 8425-8470, 2019.

Pöschl, U., Martin, S. T., Sinha, B., Chen, Q., Gunthe, S. S., Huffman, J. A., Borrmann, S., Farmer, D. K., Garland, R. M., Helas, G., Jimenez, J. L., King, S. M., Manzi, A., Mikhailov, E., Pauliquevis, T., Petters, M. D.,

30 Prenni, A. J., Roldin, P., Rose, D., Schneider, J., Su, H., Zorn, S. R., Artaxo, P., and Andreae, M. O.: Rainforest aerosols as biogenic nuclei of clouds and precipitation in the Amazon, Science, 329, 1513-1516, 10.1126/science.1191056, 2010.

Prenni, A. J., Petters, M. D., Kreidenweis, S. M., Heald, C. L., Martin, S. T., Artaxo, P., Garland, R. M., Wollny, A. G., and Pöschl, U.: Relative roles of biogenic emissions and Saharan dust as ice nuclei in the 35 Amazon basin, Nature Geoscience, 2, 401-404, 10.1038/ngeo517, 2009.

Reinmuth-Selzle, K., Kampf, C. J., Lucas, K., Lang-Yona, N., Fröhlich-Nowoisky, J., Shiraiwa, M., Lakey, P. S., Lai, S., Liu, F., and Kunert, A. T.: Air pollution and climate change effects on allergies in the anthropocene: Abundance, interaction, and modification of allergens and adjuvants, Environmental Science \& Technology, 51, 4119-4141, 2017.

40 Šantl-Temkiv, T., Sahyoun, M., Finster, K., Hartmann, S., Augustin-Bauditz, S., Stratmann, F., Wex, H., Clauss, T., Nielsen, N. W., Sørensen, J. H., Korsholm, U. S., Wick, L. Y., and Karlson, U. G.: Characterization of airborne ice-nucleation-active bacteria and bacterial fragments, Atmospheric Environment, 109, 105-117, https://doi.org/10.1016/j.atmosenv.2015.02.060, 2015.

Šantl-Temkiv, T., Sikoparija, B., Maki, T., Carotenuto, F., Amato, P., Yao, M., Morris, C. E., Schnell, R.,

45 Jaenicke, R., Pöhlker, C., DeMott, P. J., Hill, T. C. J., and Huffman, J. A.: Bioaerosol field measurements: Challenges and perspectives in outdoor studies, Aerosol Science and Technology, 1-27, 10.1080/02786826.2019.1676395, 2019.

Schmidt, H., Eickhorst, T., and Mußmann, M.: Gold-FISH: A new approach for the in situ detection of single microbial cells combining fluorescence and scanning electron microscopy, Systematic and Applied 
Schrod, J., Thomson, E. S., Weber, D., Kossmann, J., Pöhlker, C., Saturno, J., Ditas, F., Artaxo, P., Clouard, V., and Saurel, J.-M.: Long-term INP measurements from four stations across the globe, Atmospheric Chemistry and Physics Discussions, 1-37, 2020.

Souza, F. F., Rissi, D. V., Pedrosa, F. O., Souza, E. M., Baura, V. A., Monteiro, R. A., Balsanelli, E., Cruz, L. 5 M., Souza, R. A., and Andreae, M. O.: Uncovering prokaryotic biodiversity within aerosols of the pristine Amazon forest, Science of the Total Environment, 688, 83-86, 2019.

Stahl, D. A. and Amann, R.: Development and application of nucleic acid probes, Nucleic acid techniques in bacterial systematics, E. Stackebrandt and M. Goodfellow, Chichester, UK, John Wiley\&Sons Ltd, 205-248. 1991.

10 Steiner, A. L., Brooks, S. D., Deng, C., Thornton, D. C. O., Pendleton, M. W., and Bryant, V.: Pollen as atmospheric cloud condensation nuclei, Geophysical Research Letters , 42, 3596-3602, 10.1002/2015g1064060, 2015.

Thiele, S., Fuchs, B., and Amann, R.: Identification of microorganisms using the ribosomal RNA approach and fluorescence in situ hybridization, Treatise on Water Science, 3, 171-189, 2011.

15 Wallner, G., Amann, R., and Beisker, W.: Optimizing fluorescent in situ hybridization with rRNA-targeted oligonucleotide probes for flow cytometric identification of microorganisms, Cytometry, 14, 136-143, 10.1002/cyto.990140205, 1993.

Yoo, K., Lee, T. K., Choi, E. J., Yang, J., Shukla, S. K., Hwang, S.-i., and Park, J.: Molecular approaches for the detection and monitoring of microbial communities in bioaerosols: A review, Journal of Environmental

20 Sciences, 51, 234-247, https://doi.org/10.1016/j.jes.2016.07.002, 2017.

Joung, Y. S., Ge, Z. F., and Buie, C. R.: Bioaerosol generation by raindrops on soil, Nature Communications, 8, 10, 10.1038/ncomms14668, 2017.

Zeder, M., Ellrott, A., and Amann, R.: Automated sample area definition for high-throughput microscopy, Cytometry Part A, 79, 306-310, 2011. 